\title{
Disseminated Multi-system Sarcoidosis Mimicking Metastases on I8F-FDG PET/CT
}

\author{
I8F-FDG PET/BT'de Metastazı Taklit Eden Dissemine Multisistem Sarkoidoz
}

\author{
(D) William Makis I, (D) Mark Palayew2, (D) Christopher Rush2, (1) Stephan Probst2 \\ ' Cross Cancer Institute, Department of Diagnostic Imaging, Edmonton, Canada \\ 2Jewish General Hospital, Department of Nuclear Medicine, Montreal, Canada
}

\begin{abstract}
A 60-year-old female with no significant medical history presented with hematuria. A computed tomography (CT) scan revealed extensive lymphadenopathy with hypodensities in the liver and spleen, and she was referred for an 18F-fluorodeoxyglucose (18F-FDG) positron emission tomography/CT (PET/CT) study to assess for malignancy of unknown primary. PET/CT revealed extensive 18F-FDG avid lymphadenopathy as well as innumerable intensely 18F-FDG avid lung, liver and splenic nodules, highly concerning for malignancy. A PET-guided bone marrow biopsy of the posterior superior iliac spine revealed several nonnecrotizing, well-formed granulomas, consistent with sarcoidosis. The patient was managed conservatively and remained clinically well over the subsequent 9 years of follow-up.
\end{abstract}

Keywords: Sarcoidosis, artifact, mimic, lymphadenopathy, metastases, 18F-fluorodeoxyglucose, positron emission tomography

Öz

Tıbbi anamnezinde özellik olmayan 60 yaşında bir kadın hematüri ile başvurdu. Bilgisayarlı tomografide (BT) yaygın lenfadenopatiyle birlikte karaciğer ve dalakta hipodens alanlar saptanması üzerine primeri bilinmeyen malignite değerlendirilmesi amacıyla 18F-fluorodeoksiglukoz (18F-FDG) pozitron emisyon tomografisi/BT (PET/BT) için yönlendirildi. PET/ BT'de 18F-FDG tutan yaygın lenfadenopatiler ve ölçülemeyecek kadar fazla yoğun 18F-FDG tutan akciğer, karaciğer ve dalak nodülleri saptandı, malignite açısından şüpheli bulundu. PET-kılavuzluğunda posterior superior spina iliacadan yapılan kemik iliği biyopsisinde sarkoidoz ile uyumlu non-kazeifiye granülomlar saptandı. Hasta konservatif olarak takip edildi ve 9 yıllık takip süresinde klinik sorun oluşmadı.

Anahtar kelimeler: Sarkoidoz, artefakt, taklit etme, lenfadenopati, metastaz, 18F-fluorodeoksiglukoz, pozitron emisyon tomografi

Address for Correspondence: William Makis MD, Wiliam Makis Professional Corporation, Cross Cancer Institute, Department of Diagnostic Imaging, Edmonton, Canada

Phone: +07804328760 E-mail: makisw79@yahoo.com ORCID ID: orcid.org/0000-0003-0241-3426

Received: 02.10.2017 Accepted: 26.11.2017

${ }^{\circ}$ Copyright 2018 by Turkish Society of Nuclear Medicine

Molecular Imaging and Radionuclide Therapy published by Galenos Yayınevi. 

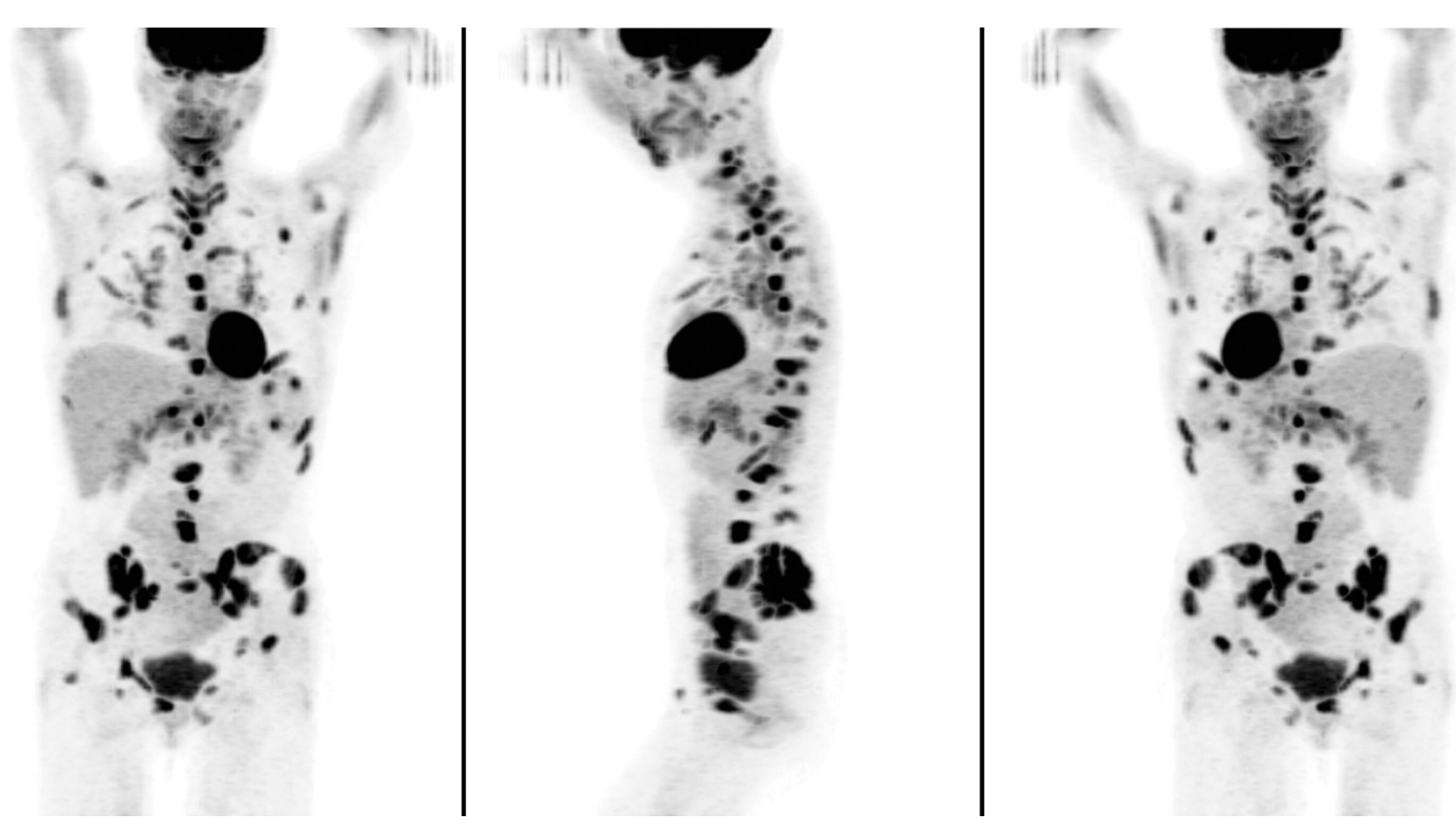

Figure 1. A 60-year-old woman, non-smoker with no significant medical history presented with recurrent hematuria. Computed tomography (CT) abdomen/pelvis identified intra-abdominal, retroperitoneal and inguinal lymphadenopathy, and small hepatic/splenic hypodensities, prompting referral for positron emission tomography/CT (PET/CT) to assess for malignancy of unknown origin. Maximum intensity projection images revealed widespread foci of intense 18 F-FDG uptake throughout the skeleton and soft-tissues.
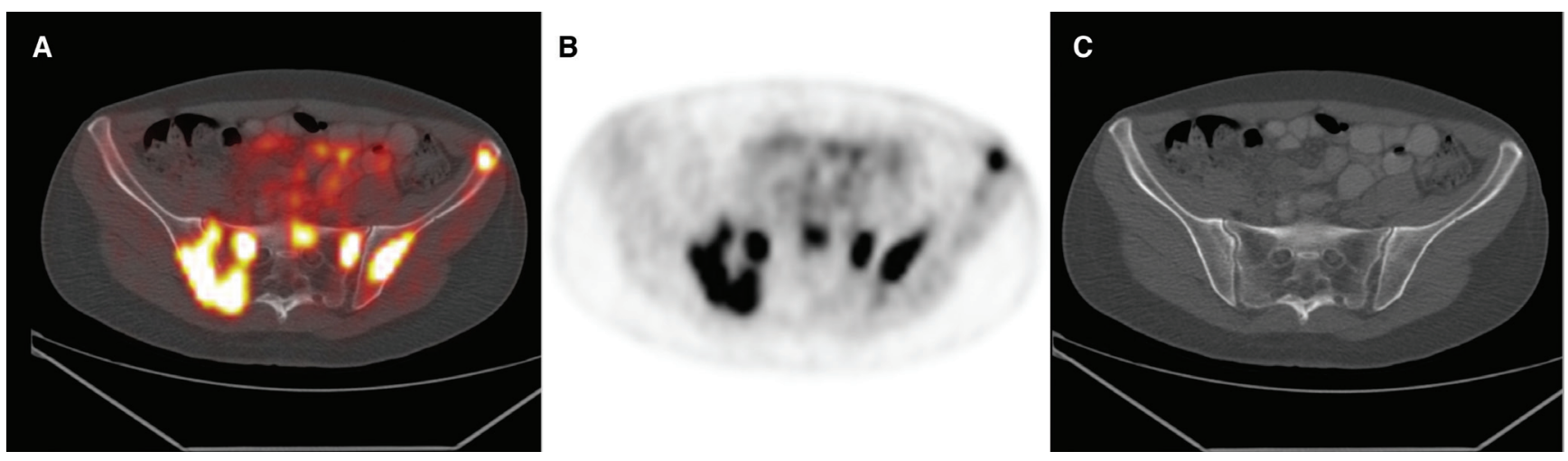

Figure 2. Transaxial (A) PET/CT fusion, (B) PET, and (C) CT images revealed extensive bone involvement of the skull base, right clavicle, spine, multiple ribs, sternum, proximal left humerus, right femur and extensively throughout the pelvis with maximum standardized uptake value $\left(S U V_{\text {max }}\right) 8.3$. 

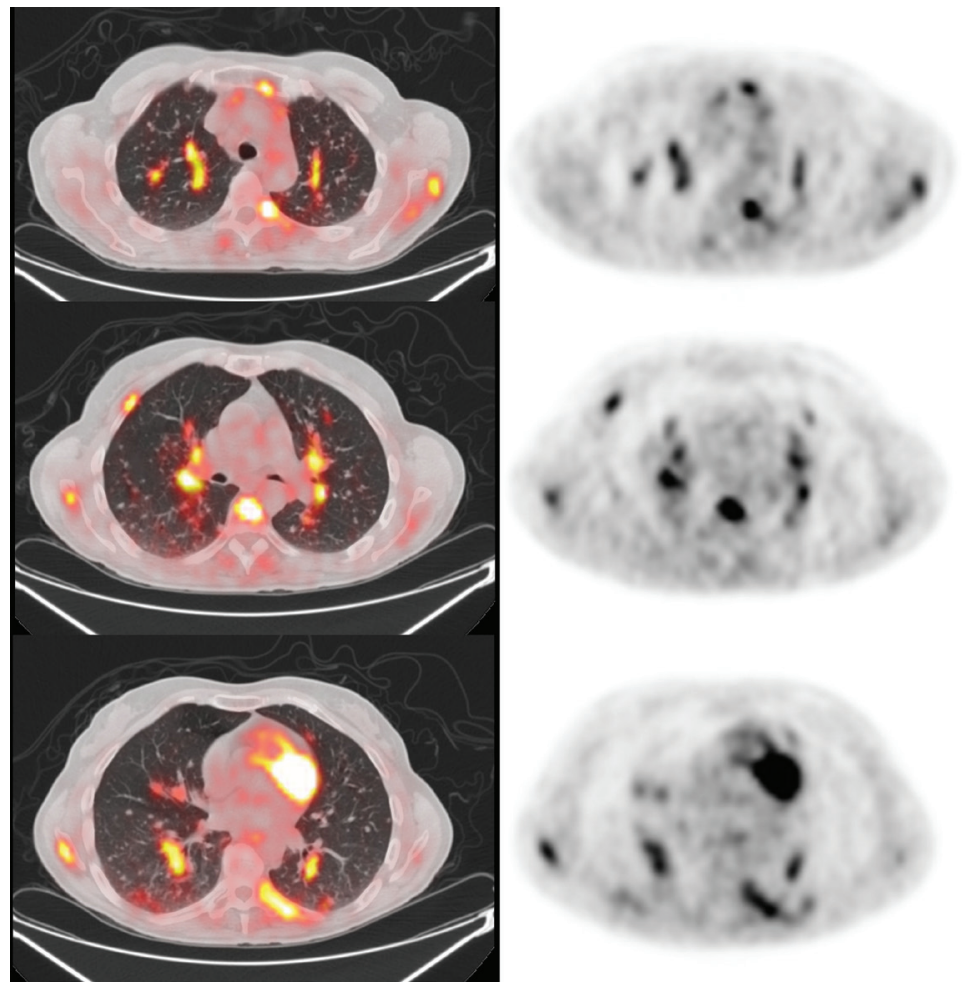

Figure 3. Intense ${ }^{18} \mathrm{~F}-\mathrm{FDG}$ uptake was also noted in numerous peribronchovascular and subpleural nodules in both lungs (largest was $1.0 \mathrm{~cm}$ in diameter with SUV max $_{3.2}$ ).
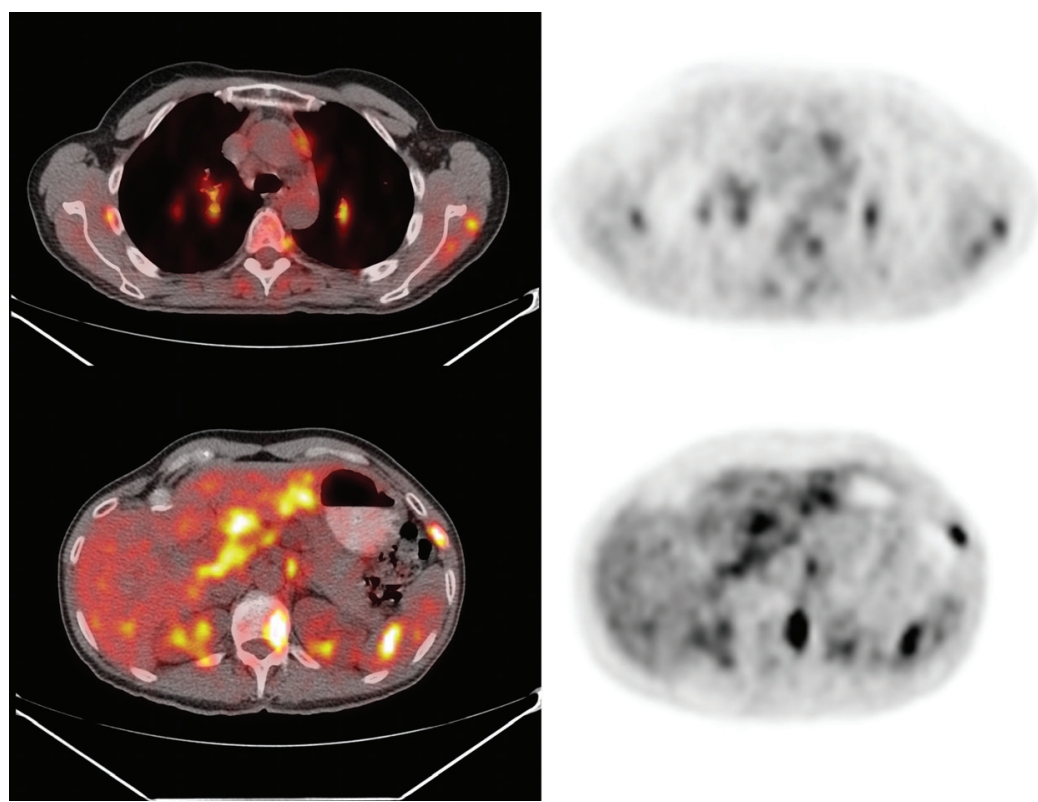

Figure 4. There was widespread adenopathy including left retromandibular, mediastinal, hilar, abdominal, retroperitoneal and inguinal nodes (largest mediastinal node measured $1.4 \mathrm{~cm}$, and the most metabolically active was a right perihilar lymph node with SUV $\mathrm{max}_{5.2}$ ). The innumerable liver and spleen hypodensities identified on CT were intensely ${ }^{18 F-F D G}$ avid with SUV ${ }_{\max } 4.3$ in the liver and 5.9 in the spleen. No primary malignancy was identified, but findings were interpreted as highly concerning for disseminated metastatic disease. The patient remained asymptomatic. PET-guided bone marrow biopsy of the left posterior superior iliac spine revealed several non-necrotizing, well-formed granulomas. These granulomas were paratrabecular in distribution and were composed of tightly apposed epithelioid histiocytes, with occasional multinucleated giant cells, consistent with sarcoidosis. 


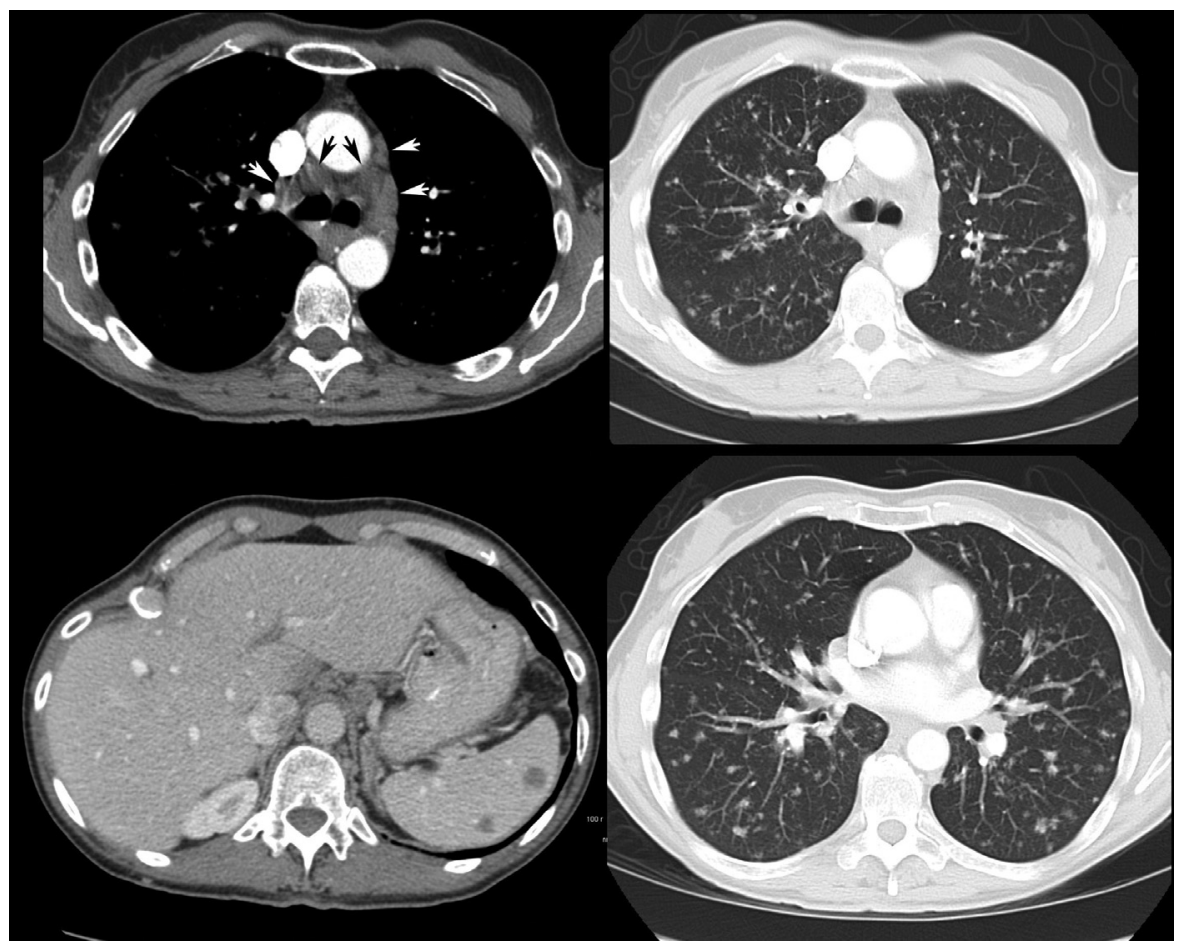

Figure 5. Follow-up diagnostic CT of chest/abdomen/pelvis performed 6 months later, again revealed extensive poorly marginated lung nodules, thoracic and abdominal lymphadenopathy, and splenic and hepatic hypodensities, unchanged as compared to prior PET/CT and consistent with stable granulomatous disease. The patient was managed conservatively with observation and remained malignancy-free over the subsequent 9 years of clinical and imaging follow-up. Sarcoidosis is a chronic multisystem granulomatous disorder of unknown etiology, which is characterized pathologically by non-caseating granulomas that can present almost anywhere in the body $(1,2,3,4)$. ${ }^{18 F}$-FDG uptake in the granulomas of sarcoidosis can be very intense, likely due to metabolic activity of activated macrophages (2,3,5). 18F-FDG-avid lesions of skeletal sarcoidosis cannot be reliably differentiated from metastases or other benign bone processes (Paget's disease, fibrous dysplasia, giant cell tumors, osteomyelitis) on the basis of semi-quantitative (SUV), visual or other analysis, and therefore remain a pitfall of oncologic PET/CT interpretation $(6,7,8,9,10)$. $18 \mathrm{~F}-\mathrm{FDG}$ uptake in pulmonary sarcoidosis lesions has been described and the severity of pulmonary involvement has been shown to be associated with $18 \mathrm{~F}-\mathrm{FDG}$ activity in persistently symptomatic sarcoidosis patients (11). CT studies show presence of hepatic and splenic nodules in approximately 5-15\% of sarcoidosis patients and splenic nodules tend to be larger than hepatic nodules (12). Intense 18F-FDG uptake in hepatic and splenic sarcoidosis lesions has been previously described (13). This case shows an uncommon presentation of disseminated sarcoidosis in the skeleton, lymph nodes, as well as organs such as the lungs, liver and spleen. This impressive pattern of disseminated ${ }^{18 F-F D G ~ u p t a k e ~ c a n ~ b e ~ e a s i l y ~ m i s t a k e n ~ f o r ~ e x t e n s i v e ~ m e t a s t a t i c ~ d i s e a s e ~}$ when interpreting oncologic PET/CT studies.

\section{Ethics}

Informed Consent: All subjects in the study gave written informed consent or the institutional review board waived the need to obtain informed consent.

Peer-review: Externally and internally peer-reviewed.

\section{Authorship Contributions}

Surgical and Medical Practices: W.M., M.P., C.R., S.P., Concept: W.M., M.P., C.R., S.P., Design: W.M., M.P., C.R., S.P., Data Collection or Processing: W.M., M.P., C.R., S.P., Analysis or Interpretation: W.M., M.P., C.R., S.P., Literature Search: W.M., M.P., C.R., S.P., Writing: W.M., M.P., C.R., S.P.

Conflict of Interest: William Makis, Mark Palayew, Christopher Rush and Stephan Probst declare that they have no conflicts of interest.
Financial Disclosure: The authors declare that this study has received no financial support.

\section{References}

1. Judson MA. Sarcoidosis: clinical presentation, diagnosis, and approach to treatment. Am J Med Sci 2008;335:26-33.

2. Aberg C, Ponzo F, Raphael B, Amorosi E, Moran V, Kramer E. FDG positron emission tomography of bone involvement in sarcoidosis. AJR Am J Roentgenol 2004;182:975-977.

3. Zhuang $\mathrm{H}$, Alavi A. 18-fluorodeoxyglucose positron emission tomographic imaging in the detection and monitoring of infection and inflammation. Semin Nucl Med 2002:32:47-59.

4. Ludwig V, Fordice S, Lamar R, Martin WH, Delbeke D. Unsuspected skeletal sarcoidosis mimicking metastatic disease on FDG positron emission tomography and bone scintigraphy. Clin Nucl Med 2003;28:176-179.

5. Cook GJ, Fogelman I, Maisey MN. Normal physiological and benign pathological variants of 18-fluoro-2-deoxyglucose positron-emission 
tomography scanning: potential for error in interpretation. Semin Nucl Med 1996;26:308-314.

6. Teirstein AS, Machac J, Almeida O, Lu P, Padilla ML, Iannuzzi MC. Results of 188 Whole Body FDG PET Scans in 137 Patients with Sarcoidosis. Chest 2007:132:1949-1953.

7. Makis W, Probst S. Extensive polyostotic fibrous dysplasia evaluated for malignant transformation with $99 \mathrm{mTc}-\mathrm{MDP}$ bone scan and 18F-FDG PET/CT. BJR Case Rep 2016;2:1-4.

8. Makis W, Stern J. Chronic vascular graft infection with fistula to bone causing vertebral osteomyelitis, imaged with F-18 FDG PET/CT. Clin Nucl Med 2010;35:794-796.

9. Aoki J, Watanabe H, Shinozaki T, Takagishi K, Ishijima H, Oya N, Sato N, Inoue T, Endo K. FDG PET of primary benign and malignant bone tumors: standardized uptake value in 52 lesions. Radiology 2001;219:774-777.
10. Kobayashi A, Shinozaki T, Shinjyo Y, Kato K, Oriuchi N, Watanabe $H$, Takagishi K. FDG PET in the clinical evaluation of sarcoidosis with bone lesions. Ann Nucl Med 2000;14:311-313.

11. Sobic-Saranovic $D$, Artiko $V$, Obradovic $V$. FDG PET imaging in sarcoidosis. Semin Nucl Med 2013;43:404-411.

12. Warshauer DM, Molina PL, Hamman SM, Koehler RE, Paulson EK, Bechtold RE, Perlmutter ML, Hiken JN, Francis IR, Cooper CJ, et al. Nodular sarcoidosis of the liver and spleen: analysis of 32 cases. Radiology 1995:195:757-762.

13. Soussan $M$, Augier $A$, Brillet PY, Weinmann P, Valeyre D. Functional imaging in extrapulmonary sarcoidosis: FDG-PET/CT and MR features. Clin Nucl Med 2014;39:e146-159. 